положения в социуме, выполнению своих прав и обязанностей, как гражданина своей страны и готовых трудится на благо Родины.

$* * *$

1. Федеральный закон «Об образовании в Российской Федерации» от 29.12.2012 N 273-Ф3

2. Распоряжение Правительства РФ от 12.11.2020 N 2945-Р «Об утверждении плана мероприятий по реализации в 2021 - 2025 годах Стратегии развития воспитания в Российской Федерации на период до 2025 года» http://www.consultant.ru/law/hotdocs/65751.html/ (дата обращения 22.03.2021 г.)

3. Федеральный проект «Патриотическое воспитание граждан Российской Федерации» (до 31.12.2024 г.) https://unpo.tomsk.gov.ru/Files/d2157632-10ad-47cc-8dfd$77328967 \mathrm{dd} 5 \mathrm{c} / \% \mathrm{D} 0 \% 9 \mathrm{~F} \% \mathrm{D} 0 \% \mathrm{~B} 0 \% \mathrm{D} 1 \% 81 \% \mathrm{D} 0 \% \mathrm{BF} \% \mathrm{D} 0 \% \mathrm{BE} \% \mathrm{D} 1 \% 80 \% \mathrm{D} 1 \% 82 \% 20 \% \mathrm{D} 1 \% 84 \% \mathrm{D} 0$ $\%$ B5\%D0\%B4\%D0\%B5\%D1\%80\%D0\%B0\%D0\%BB\%D1\%8C $\%$ D0\%BD $\%$ D0\%BE $\%$ D0\%B3\%D0\%B E\% $20 \% \mathrm{D} 0 \% \mathrm{BF} \% \mathrm{D} 1 \% 80 \% \mathrm{D} 0 \% \mathrm{BE} \% \mathrm{D} 0 \% \mathrm{~B} 5 \% \mathrm{D} 0 \% \mathrm{BA} \% \mathrm{D} 1 \% 82 \% \mathrm{D} 0 \% \mathrm{~B} 0 \% 20 \% \mathrm{D} 0 \% 9 \mathrm{~F} \% \mathrm{D} 0 \% \mathrm{~B} 0 \% \mathrm{D}$ $1 \% 82 \% \mathrm{D} 1 \% 80 \% \mathrm{D} 0 \% \mathrm{~B} 8 \% \mathrm{D} 0 \% \mathrm{BE} \% \mathrm{D} 1 \% 82 \% \mathrm{D} 0 \% \mathrm{~B} 8 \% \mathrm{D} 1 \% 87 \% \mathrm{D} 0 \% \mathrm{~B} 5 \% \mathrm{D} 1 \% 81 \% \mathrm{D} 0 \% \mathrm{BA} \% \mathrm{D} 0 \% \mathrm{~B}$ E\%D0\%B5\%20\%D0\%B2\%D0\%BE\%D1\%81\%D0\%BF\%D0\%B8\%D1\%82\%D0\%B0\%D0\%BD\%D0\% $\mathrm{B} 8 \% \mathrm{D} 0 \% \mathrm{~B} 5 . \mathrm{pdf}$ (дата обращения 22.03.2021 г.)

4. Киселев Н.Н., Киселева Е.В. Воспитание в вузе: исторические традиции, современные тенденции // Сибирский педагогический журнал. 2014. №2. URL: https:/cyberleninka.ru/article/n/vospitanie-vvuze-istoricheskie-traditsii-sovremennye-tendentsii (дата обращения: 23.03.2021).

5. Нив Генри Р. Пространство доктора Деминга: Принципы построения устойчивого бизнеса. М.: Альпина Бизнес Букс, 2005. - 370 с.

6. Мурзина И.Я., Казакова С.В. Перспективные направления патриотического воспитания // Образование и наука. 2019. Т. 21. № 2. C. 155-175. DOI: 10.17853/1994-5639-2019-2-155-175

7. Дорофеев А.М., Тимченко П.В., Туктаров Р.Р. Военно-патриотическое воспитание курсантов морского вуза: сущность и определение // Научный журнал КубГАУ. 2015. №110. URL: https://cyberleninka.ru/article/n/voenno-patrioticheskoe-vospitanie-kursantov-morskogo-vuza-suschnosti-opredelenie (дата обращения: 2403.2021).

8. Милованова И.Г., Удилова И.Я. Военно-историческая реконструкция, как одна из инновационных форм военно-патриотического воспитания молодежи // Бюллетень науки и практики. 2016. №12 (13). URL: https://cyberleninka.ru/article/n/voenno-istoricheskaya-rekonstruktsiya-kak-odna-izinnovatsionnyh-form-voenno-patrioticheskogo-vospitaniya-molodezhi (дата обращения: 24.03.2021).

\title{
Стрекатова Т.А., Шамовская Т.В. \\ К вопросу формирования слоговой структуры слова у детей старшего дошкольного возраста с общим недоразвитием речи
}

ФГБОУ ВО «Кемеровский государственный университет» (Россия, Кемерово)

doi: 10.18411/lj-04-2021-172

\section{Аннотация}

Статья посвящена рассмотрению вопросов, составляющих научную базу проблемы формирования слоговой структуры слова у детей с общим недоразвитием речи. Описаны механизмы, значимые для становления процессов слогового оформления слов в онтогенезе у старших дошкольников, имеющих тяжёлые речевые нарушения с учётом психолого-педагогических и организационно-методических условий, способствующих эффективному усвоению слоговой структуры слова.

Ключевые слова: слог, слоговая структура слова, общее недоразвитие речи, фонематическое восприятие, тяжёлые нарушения речи.

\section{Abstract}

The article is devoted to the consideration of the issues that make up the scientific basis of the problem of the formation of the syllabic structure of the word in children with general speech underdevelopment. The mechanisms that are important for the formation of the processes of syllabic word formation in ontogenesis in older preschoolers with severe speech disorders are described, taking into account the psychological, pedagogical, 
organizational and methodological conditions that contribute to the effective assimilation of the syllabic structure of the word.

Keywords: syllable, syllabic structure of the word, general speech underdevelopment, phonemic perception, severe speech disorders.

Проблема формирования слоговой структуры слова у детей старшего дошкольного возраста с общим недоразвитием речи актуальна в настоящее время. Так как усвоение слоговой структуры слова это одна из предпосылок овладения грамотой и дальнейшего успешного обучения ребенка в школе. Ведь своевременное овладение правильной речью имеет большое значение для становления полноценной личности ребенка.

У детей с тяжёлыми нарушениями речи слоговая структура слова имеет выраженные отклонения. О важности данной проблемы свидетельствует и тот факт, что недостаточная степень коррекции данного вида фонологической патологии в дошкольном возрасте впоследствии приводит к возникновению у школьников ошибок на письме и при чтении (дислексии и дисграфии). Ученые, занимавшиеся изучением данного вопроса, отмечают стойкость этого дефекта и низкую динамику его преодоления.

Анализ отечественных литературных источников показал, что вопросы, касающиеся слога, слогосложения и слогоделения, были представлены в различных научных областях: лингвистике и психолингвистике, психологии и педагогике, физиологии и др. Понятие «слог», «слоговая структура слова» рассматривается поразному. Так при изучении процесса формирования слоговой структуры слова Лурия А.Р. отмечал, что слоговая структура слова представляет собой некую кинетическую артикуляционную программу, или структуру, лежащую в основе образования плавных, протекающих во времени двигательных навыков [1]. На усвоение такой программы влияют компоненты самой слоговой структуры слова - это ударность, количество слогов и их последовательность, структура слога.

В работах Жинкина Н.И. подчеркивается единство звуковой и слоговой структур. С одной стороны, вне слога не может быть произнесен ни один звук речи и без него не может образоваться ни одна языковая единица. Вместе с тем звуки, синтезируясь в слоговом составе, обеспечивают не только узнавание слов, но и облегчают сцепление самих слогов путем слияния [2].

Маркова А.К. определяет слоговую структуру слова как чередование ударных и безударных слогов различной степени сложности. «Под овладением слоговой структурой слова понимается овладение нужным (адекватным) количеством слогов в нём. Адекватной считается такая структура слова, в которой сохраняется необходимое количество слогов» [3].

Определение слогу дает и энциклопедический словарь: «Слог - это минимальная произносительная единица речи, состоящая из одного или нескольких звуков, которые образуют тесное фонетическое единство».

Не смотря на некие расхождения в определении понятий термин «структура слова» трактуется как соотношение частей звуковых единиц, это отрезок звуковой цепи, объединенный одним словесным ударением (Касаткин Л.Л., Клобуков Е.В.) [4].

По данным различных источников возрастной предел, с которым связывают овладение ребенком структурными особенностями слов родного языка, определен трехлетним возрастом. То есть к трем годам ребенок способен воспроизводить структуру любой степени сложности. Исключения могут составлять слова многосложной слоговой структуры и недоступной указанному возрасту семантики (паспортистка, квартиросъемщик и др.)

У детей старшего дошкольного возраста с общим недоразвитием речи имеются выраженные отклонения в воспроизведении слогового состава слова. Общее 
недоразвитие речи относится к тяжелой речевой патологии, речь страдает, как целостная функциональная система, при которой нарушаются все ее компоненты.

Так как термин «общее недоразвитие речи» характеризует речевую функцию как неполноценную, то все конструкции языка, такие как лексическая, грамматическая и фонематическая, отличаются несформированностью. У дошкольников с общим недоразвитием речи наблюдается бедность активного словаря (на бытовом уровне), отсюда неточность и сложность в употреблении слов; трудность в словообразовании и словоизменении; преобладание в связной речи глаголов; очень редкое употребление прилагательных, a особенно наречий; часто наблюдаются недостатки звукопроизношения и специфические ошибки в слоговой структуре слова. Эти отклонения носят тот или иной характер изменений правильного слогового звучания.

Впервые теоретическое обоснование общего недоразвития речи было сформулировано Левиной P.Е. и коллективом научных сотрудников НИИ дефектологии в 50-60 годах XX века. Явные отклонения в формировании речи стали рассматриваться как нарушения развития, протекающие по законам иерархического строения высших психических функций. Под общим недоразвитием речи у детей с нормальным слухом и первично сохранным интеллектом ученые понимали такую форму речевой патологии, при которой нарушено формирование всех компонентов речевой системы, относящихся как к смысловой сторонам речи, так и к звуковой [1].

Позже, такие исследователи, как Гвоздев А.Н., Сикорский И.А., Швачкин Н.Х., Китерман Б. определили общее недоразвитие речи как нарушение процессов формирования произносительной системы родного языка у детей с различными речевыми расстройствами вследствие дефектов восприятия и произношения фонем [1].

Учитывая общие закономерности онтогенеза в условиях нормального и аномального развития, изучение процесса формирования слоговой структуры слова у детей с речевыми отклонениями имеет свои особенности. Поэтому дети с общим недоразвитием речи не могут спонтанно стать на онтогенетический путь развития речи, который свойственен нормальным детям.

Над проблемой формирования слоговой структуры слов работали многие авторы: так в научных трудах Левиной Р.Е., Марковой А.К., Трауготт Н.Н., Орфинской В.К. выделена специфика усвоения структурного состава слова дошкольниками с различными формами дизонтогенеза. Определена типология искажений ритмических и слоговых структур слова, обозначены направления коррекции имеющихся дефектов [5].

В своих исследованиях Бабина Г.В., Ковшикова В.А, Соботович Е.Ф., Садовникова И.Н., Усанова О.Н., Филичева Т.Б, Шаховская С.Н. охарактеризовали закономерность процессов слогового оформления слова с формированием фонемного анализа, усвоением грамматических категорий и звукового состава [5].

Спирова Л.Ф., Т.Б. Филичева Т.Б., Чиркина Г.В. и др. в своих работах доказали, что основополагающий диагностический показатель в структуре системного речевого нарушения это искажения слогового состава слова. Данный показатель выявляет как наличие недоразвития речи, так и степень его выраженности. По их мнению, слоговая структура слова характеризуется четырьмя параметрами, такими как: 1) ударность, 2) количество слогов, 3) модель самого слога, 4) линейная последовательность слогов [6].

Принято считать, что нарушения слоговой структуры по-разному видоизменяют слоговой состав слова. Четко выделяются искажения, состоящие в выраженном нарушении слогового состава слова. По наблюдениям Марковой А.К. слова могут быть деформированы за счет: нарушения в слове количества слогов, последовательности слогов в слове; искажения структуры отдельного слога; уподобления слогов; персеверации; антиципации; контаминации [7].

Все перечисленные виды искажений слогового состава слова распространены у детей с общим недоразвитием речи. Слоговые искажения встречаются у детей на 
разных ступенях слоговой трудности. Их задерживающее влияние на процесс овладения речью усугубляется еще и тем, что они отличаются большой стойкостью.

Учитывая многолетние исследования, прослеживается закономерность в том, что процесс усвоения слогового состава слова тесно связан с речевым развитием в целом и с состоянием фонематических или моторных возможностей ребенка в частности. Следовательно, искажение слова обусловлено спецификой и уровнем речевого недоразвития. С одной стороны недоразвитие речи определяет недостатки овладения слоговым составом слова посредством отклонения в сенсорной сфере и возникающие вследствие этого трудности в различении слоговых контуров. С другой несформированность артикуляционной сферы способствует появлению затруднений в повторении слоговых контуров и объединении разных слогов в ряд.

То есть, недостаточность, бедность активного словаря в свою очередь, задерживает формирование слоговой структуры слова.

Необходимо также выделить и другие факторы, препятствующие формированию слоговой структуры слова у детей старшего дошкольного возраста с общим недоразвитием речи:

— неврологический статус (сниженная работоспособность, познавательная и речевая активность, эмоциональная неустойчивость и нарушение темпо-ритмической организации речи, несформированность общей и мелкой моторики и др.);

- психологические особенности детей-логопатов (замедленное формирование произвольной регуляции поведения и действий, двигательная расторможенность и повышенная возбудимость, неустойчивость внимания, несформированность регулирующей, коммуникативной и когнитивной функций речи и др.).

Очевидно, что долгий процесс «стихийного» формирования слоговой структуры слова необходимо заменить сознательным и целенаправленным процессом обучения. В своих исследованиях Маркова А.К. подчеркивала неоспоримую связь при овладении слоговым составом слова с мотивационной стороной деятельности ребенка, а также состоянием его слухового (фонематического) восприятия и уровнем артикуляционных возможностей. Она же подтверждала, что вследствие искажений слогового состава слова затрудняется общение дошкольников [7].

В специальной литературе описаны несколько авторских методик по формированию слоговой структуры слова (Агранович 3.Е.; Большаковой Е.С.; Четверушкиной Н.С. и др.). Многие авторы сходятся во мнении, что для становления слоговой структуры слова значимыми являются такие неречевые процессы, как возможности темпо-ритмической организации движений и действий, способность к серийно-последовательной обработке информации, оптико-пространственная ориентация. А также: артикуляционные возможности каждого ребенка; ритмическая и динамическая организация движений; состояние фонематического восприятия; слуховое восприятие и мотивационная сфера ребенка с общим недоразвитием речи [8].

Несомненно, что при формировании слоговой структуры слова у детей старшего дошкольного возраста с общим недоразвитием речи обязательно должны учитываться психолого-педагогические и организационно-методические условия, способствующие эффективному усвоению слоговой структуры слова:

— организация коррекционной работы в условиях логопедической группы;

— грамотная организация предметно-развивающей среды в дошкольном учреждении;

— взаимодействие всех педагогов, работающих с данной категорией детей;

- привлечение родителей и лиц, их заменяющих к сотрудничеству в вопросах коррекции недостатков высших психических функций; 
- рациональное сочетание методов и приемов с учетом индивидуальных различий детей;

- использование инновационных, интерактивных методов в коррекционно-воспитательном процессе;

- обязательное использование различного стимульного материала.

То есть, при формировании (и коррекции) слоговой структуры слова у детей с общим недоразвитием речи следует учитывать принцип системного подхода.

Таким образом, понимание процесса усвоения структуры родного языка детьми c тяжелой речевой патологией обеспечивает специалисту выбор наиболее рациональных и эффективных путей преодоления у них общего недоразвития речи, а значит эффективного формирования слоговой структуры слова.

1. Левина, Р.Е. Нарушение слоговой структуры слова у детей // Специальная школа. - 1959. - № 4. С. 86-89. Текст: непосредственный.

2. Жинкин, Н. И. Механизмы речи / Н. И. Жинкин. - М.: Изд-во АПН РСФСР, 1958. - 370 с. - Текст: непосредственный.

3. Маркова, А. К. Особенности усвоения слоговой структуры слова у детей, страдающих алалией // Школа для детей с тяжелыми нарушениями речи. - М.: Просвещение, 1961. - С. 59-70. - Текст: непосредственный.

4. Китаева, Н.Н. Работа по коррекции слоговой структуры слова у дошкольников с моторной алалией //Речевая деятельность в норме и патологии: Материалы межотраслевой научно-методической конференции.-СПб.: РГПУ им. А.И. Герцена, 1999. - С. 65-68. - Текст: непосредственный.

5. Бабина, Г.В., Сафонкина Н.Ю. Слоговая структура слова: обследование и формирование у детей с недоразвитием речи: учеб.-метод. пособие. - М.: Книголюб, 2005. - 96 с. ISBN 5-93927-146-4 Текст: непосредственный.

6. Филичева, Т. Б. Воспитание и обучение детей дошкольного возраста с общим недоразвитием речи. Программно-методические рекомендации / Т. Б. Филичева, Т. В. Туманова, Г. В. Чиркина. - 2-е изд., стер. - Москва: Дрофа, 2010. - 189 с. - ISBN 978-5-358-08661 - Текст: непосредственный.

7. Маркова, А.К. О работе по преодолению нарушений слоговой структуры слова у детей, страдающих алалией // Спец. шк. - 1961. - Вып. 4. - С. 46-53. Текст: непосредственный.

8. Агранович, 3.Е. Логопедическая работа по преодолению нарушений слоговой структуры слов у детей. - СПб., 2001. - 48 с. - ISBN 5-89814-072-7 - Текст: непосредственный.

\section{Суфиянов Р.ШІ. \\ К вопросу о совершенствовании образовательного процесса}

Бронницкий филиал ФГБОУ ВО «Московский автомобильно-дорожный государственный технический университет (МАДИ)»

doi: 10.18411/lj-04-2021-173

(Россия, Бронницы)

\section{Аннотация}

В статье рассмотрены вопросы обеспечения качественной подготовки специалистов с инженерным техническим образованием, основанной на изучении современных технологий с использованием виртуальных лабораторных работ. В системе высшего образования необходимо формировать творческое отношение студентов к учебным дисциплинам, использовать их увлечение информационнокоммуникационными технологиями и электронными образовательными ресурсами для самообразования, и для участия в научно-исследовательских работах.

Ключевые слова: Подготовка кадров, виртуальные лабораторные работы, современное оборудование, научно-исследовательская работа, инженерная подготовка.

\section{Abstract}

The article deals with the issues of providing high-quality training of specialists with engineering and technical education, based on the study of modern technologies using virtual 